\title{
PENYEBAB KETERLAMBATAN PENYAMPAIAN LAPORAN KEUANGAN PADA SATUAN KERJA (SATKER) PADA KPPN SOLOK PERIODE 2017
}

\author{
Mirawati, Nesa Yuliantika \\ Institut Agama Islam Negeri Batusangkar, Sumatera Barat \\ mirawati@iainbatusangkar.ac.id
}

\begin{abstract}
In the 2017 period, the working unit of the Solok State Treasury Office (KPPN) area, often experienced delays in the submission of financial reports (Operator verification and accounting of KPPN Solok). This type of field research uses qualitative methods, the primary data source is Mr. In Setyo Utomo as the head of the accounting verification section and Mr. Nofa Putra as the executor of accounting verification and work units that experience delays in reporting. The factors that cause delays in the delivery of financial statements in the work unit in KPPN Solok first are the lack of competent human resources in the delivery of financial reports, secondly the lack of information technology that causes delays so that reporting is not timely, thirdly a lack of supporting facilities, fourthly a lack of internal control systems clear division of tasks within the organization, and the last is the rule of law in which employees lack understanding in preparing financial statements in accordance with the PP on Financial Reporting.
\end{abstract}

Keywords: Financial Statements, Work Units

\begin{abstract}
ABSTRAK
Pada periode 2017 satuan kerja lingkup wilayah Kantor Pelayanan Perbendaharaan Negara (KPPN) Solok, sering mengalami keterlambatan dalam penyampaian laporan keuangan (Operator verifikasi dan akuntansi KPPN Solok). Jenis penelitian field research dengan menggunakan metode kualitatif, sumber data primer adalah Bapak In Setyo Utomo sebagai kepala seksi verifikasi akuntansi dan Bapak Nofa Putra sebagai pelaksana verifikasi akuntansi dan satuan kerja yang mengalami keterlambatan pelaporan. Faktor-faktor penyebab keterlambatan penyampaian laporan keuangan pada satuan kerja di KPPN Solok yang pertama adalah kurangnya SDM yang kompeten dalam penyampaian laporan keuangan, kedua kurangnya teknologi informasi yang menyebabkan keterlambatan sehingga tidak tepat waktu pelaporan, ketiga kurangnya sarana pendukung, keempat sistem pengendalian internal yang kurang jelas pembagian tugas dalam organisasi tersebut, dan yang terakhir adalah aturan hukum dimana para pegawai kurang memahami dalam penyusunan laporan keuangan yang sesuai dengan PP tentang Pelaporan Keuangan.
\end{abstract}

\section{Kata Kunci : Laporan Keuangan, Satuan Kerja}




\section{PENDAHULUAN}

\section{Latar Belakang}

Laporan keuangan merupakan suatu bentuk pertanggung jawaban manajemen dalam mengelola sumber daya yang dipercayakan kepadanya. Seperti yang tertuang dalam Peraturan Pemerintah Republik Indonesia Nomor 71 Tahun 2010 tentang Standar Akuntansi Pemerintahan (SAP) yang menyatakan bahwa informasi yang disajikan dalam laporan keuangan bertujuan umum untuk memenuhi kebutuhan informasi dari semua kelompok pengguna. Salah satu syarat agar laporan keuangan dapat dikatakan relevan jika laporan keuangan tersebut dapat dilaporkan secara tepat waktu

Dalam pengelolaan keuangan pemerintah yang baik, satuan kerja harus memiliki sumber daya manusia yang berkualitas dengan pemahaman akuntansi yang memadai didukung pelatihan serta latar belakang pendidikan yang sesuai. Selain itu juga harus mengikuti teknologi informasi yang mendukung. Satuan kerja juga harus patuh terhadap aturan hukum yang telah ditetapkan.

Satuan Kerja yang ada di wilayah kerja Kantor Pelayanan Perbendaharaan Negara (KPPN) Solok membawahi 1 Kota Dan 2 Kabupaten di Wilayah Provinsi Sumatera Barat Yakni : Kabupaten Solok, Kabupaten Solok Selatan Dan Kota Solok. Jumlah seluruh satuan kerja dari 3 Kabupaten/Kota sebanyak 84 satuan kerja. Kantor Pelayanan Perbendaharaan Negara Solok mempunyai tugas melaksanakan sebagian kewenangan perbendaharaan dan kuasa bendahara umum yaitu menyalurkan dana atas beban anggaran dan membukukan penerimaan dan pengeluaran anggaran melalui kas negara berdasarkan peraturan perundang-undangan yang berlaku. Untuk melaksanakan tugas tersebut, Kantor Pelayanan Perbendaharaan Negara (KPPN) Solok mempunyai fungsi menyelenggarakan verifikasi transaksi keuangan, akuntansi, dan pelaporan.

Pada Peraturan Menteri Keuangan Republik Indonesia Nomor 210/PMK.05/2013 dijelaskan bahwa Unit Akuntansi Kuasa Pengguna Anggaran (UAKPA) dan Unit Akuntansi Kuasa Pengguna Anggaran Bendahara Umum Negara (UAKPA BUN) dengan Unit Akuntansi Kuasa Bendahara Umum Negara Daerah KPPN (UAKBUN-D/KPPN) wajib melakukan rekonsiliasi setiap bulan dengan melampirkan laporan pertanggungjawaban bendahara. Rekonsiliasi ini dilaksanakan paling lambat tanggal 10 setelah bulan bersangkutan 
berakhir. Jika tanggal 10 tersebut jatuh pada hari libur maka rekonsiliasi dilaksanakan paling lambat pada hari kerja sebelumnya. UAKPA dan UAKPA BUN yang tidak atau terlambat melakukan rekonsiliasi akan dikenakan sanksi administratif.

Pada periode 2017 satuan kerja lingkup wilayah Kantor Pelayanan Perbendaharaan Negara (KPPN) Solok sering mengalami keterlambatan dalam penyampaian laporan keuangan (Operator verifikasi dan akuntansi KPPN Solok). Berikut daftar keterlambatan penyampaian laporan keuangan oleh satuan kerja ke Kantor Pelayanan Perbendaharaan Negara (KPPN) Solok di bulan Juli sampai November tahun 2017 adalah sebagai berikut :

Tabel 1.1

\section{Data Satker Yang Terlambat Dalam Menyampaikan Laporan keuangan di KPPN Solok Periode Juli Sampai November 2017}

\begin{tabular}{|c|c|c|c|}
\hline No & Nama Satker & Periode keterlambatan & Pelaporan keuangan \\
\hline 1 & $\begin{array}{l}\text { MAN Solok Kota } \\
\text { Solok }\end{array}$ & $\begin{array}{l}\text { Juli, September dan } \\
\text { November }\end{array}$ & $\begin{array}{l}14 \text { Agustus , } 20 \text { Oktober } \\
\text { dan } 11 \text { Desember }\end{array}$ \\
\hline 2 & $\begin{array}{l}\text { MTSN Tembok } \\
\text { Kacang Kab. Solok }\end{array}$ & $\begin{array}{l}\text { September dan } \\
\text { November }\end{array}$ & $\begin{array}{l}14 \text { Oktober dan } 15 \\
\text { Desember }\end{array}$ \\
\hline 3 & Polres Kota Solok & $\begin{array}{l}\text { Juli, Oktober dan } \\
\text { November }\end{array}$ & $\begin{array}{l}24 \text { Agustus, } 12 \\
\text { November dan } 18 \\
\text { Desember }\end{array}$ \\
\hline 4 & $\begin{array}{l}\text { Dinas Pertanian } \\
\text { Kab. Solok }\end{array}$ & $\begin{array}{l}\text { Juli, September dan } \\
\text { November }\end{array}$ & $\begin{array}{l}12 \text { Agustus, } 18 \text { Oktober } \\
\text { dan } 14 \text { Desember }\end{array}$ \\
\hline 5 & $\begin{array}{l}\text { MTSN Koto Baru } \\
\text { Solok }\end{array}$ & $\begin{array}{l}\text { Juli, Agustus dan } \\
\text { Oktober }\end{array}$ & $\begin{array}{l}11 \text { Agustsus, } 16 \\
\text { September dan } 13 \\
\text { November }\end{array}$ \\
\hline 6 & $\begin{array}{l}\text { Kementerian } \\
\text { Agama Kota Solok }\end{array}$ & $\begin{array}{l}\text { Juli, September dan } \\
\text { Oktober }\end{array}$ & $\begin{array}{l}25 \text { Agustus, } 19 \text { Oktober } \\
\text { dan } 26 \text { November }\end{array}$ \\
\hline 7 & $\begin{array}{l}\text { KPU Kab. Solok } \\
\text { Selatan }\end{array}$ & $\begin{array}{l}\text { September dan } \\
\text { Oktober }\end{array}$ & $\begin{array}{l}14 \text { Oktober dan } 15 \\
\text { November }\end{array}$ \\
\hline & Pengadilan Negeri & Oktober dan November & 15 November dan 13 \\
\hline
\end{tabular}




\begin{tabular}{|c|c|c|c|}
\hline 8 & Solok & & Desember \\
\hline 9 & $\begin{array}{l}\text { Pengadilan Agama } \\
\text { Solok }\end{array}$ & Oktober dan November & $\begin{array}{l}13 \text { November dan } 17 \\
\text { Desember }\end{array}$ \\
\hline 10 & KPU Kota Solok & $\begin{array}{l}\text { Juli, September dan } \\
\text { November }\end{array}$ & $\begin{array}{l}11 \text { Agustus, } 15 \text { Oktober } \\
\text { dan } 20 \text { Desember }\end{array}$ \\
\hline
\end{tabular}

Sumber : Dari seksi verifikasi dan akuntansi KPPN Solok

Sedangkan pada karakteristik kualitatif penyampaian laporan keuangan yang tertuang dalam kerangka konseptual Standar Akuntansi Pemerintah bahwa laporan keuangan harus disampaikan tepat waktu agar dapat digunakan untuk pengambilan keputusan.

\section{Faktor-faktor yang mempengaruhi keterlambatan penyampaian laporan keuangan.}

1. Sumber Daya Manusia

Memberikan perhatian kepada unsur manusia merupakan salah satu tuntutan dalam keseluruhan upaya meningkatkan produktivitas kerja (Sondang P. Siagian. 2009: 2)

a. Pemahaman Akuntansi

Dari pengalaman dan praktek, banyak manajer dan para akuntan telah memperoleh suatu pemahaman yang lebih besar dari aspek manusia tentang tugas mereka. Harus diakui, bagaimanapun juga banyak sistem akuntansi masih dihadapkan pada berbagai kesulitan manusia yang tidak terhitung, bahkan penggunaan dan penerimaan seluruh sistem akuntansi terkadang dapat merugikan (Mardiasmo, 2009:27).

b. Pelatihan

Program pelatihan dan pengembangan merupakan serangkaian aktivitas yang dirancang untuk meningkatkan pengetahuan, kemampuan, keterampilan, sikap dan kinerja sumber daya manusia. Aktivitas pelatihan ini mengajarkan keahlian baru, memperbaiki keahlian yang ada dan mempengaruhi sikap dan tanggung jawab para karyawan. Aktivitas pengembangan dirancang untuk mendidik 
karyawan sehingga mereka siap dipromosikan dan mampu memandang peran mereka dalam organisasi secara luas. Pengembangan sumber daya manusia dibutuhkan karena pekerjaan selalu berubah (Sadeli,dkk, 2015:39).

2. Teknologi Informasi

Dalam menjalankan tugas dan wewenangnya, semua informasi untuk menjalankan fungsi-fungsinya seperti perencanaan, pembuat kebijakan, administrasi negara dan lain sebagainya. Informasi yang terkait dengan pelaksanaan fungsi dan wewenang pemerintah diproses oleh suatu sistem informasi untuk:
a. Mengumpulkan informasi
b. Mengklasifikasi informasi
c. Mengolah informasi
d. Menginterpretasikan informasi
e. Mengambil informasi di tempat penyimpanan
f. Transmisi (penyampaian)
g. Penggunaan informasi. (Sutabri, $2014: 22$ ).

3. Sarana Pendukung.

Sarana dan prasarana yang mendukung sangat menentukan terhadap penyelesaian suatu pekerjaan.

a. Komputer

Penggunaan sistem komputer akan memberikan dukungan yang sangat berarti untuk memperoleh data tepat waktu, karena komputer mampu mengolah data dengan kecepatan yang sangat tinggi.

b. Jaringan Internet.

Internet (INTERnational NETwork) dapat diartikan sebagai jaringan komputer internasional, ribuan sistem komputer saling berhubungan satu dengan yang lainnya. Kehadiran internet telah membiaskan batas-batas negara sehingga berbagai informasi penting dapat dengan cepat dan sangat mudah didistribusikan ke seluruh penjuru dunia, maka abad ini kemudian disebut sebagai abad informasi (Yakup, $2012: 104$ ). 
4. Sistem Pengendalian Internal

Sistem pengendalian intern adalah suatu proses yang dipengaruhi oleh manajemen yang diciptakan untuk memberikan keyakinan yang memadai dalam pencapaian efektifitas, efesiensi, ketaatan terhadap peraturan perundang-undangan yang berlaku, dan keandalan penyajian laporan keuangan pemerintah (Peraturan Pemerintah, 2015).

\section{Aturan Hukum}

Aturan hukum penyampaian laporan keuangan peraturan pemerintah republik indonesia nomor 8 tahun 2006 tentang pelaporan keuangan dan kinerja instansi pemerintah bahwa dalam rangka pertanggung jawaban pelaksana APBN/APBD, setiap entitas pelaporan wajib menyusun dan menyajikan laporan keuangan dan laporan kinerja. Jika terjadi keterlambatan penyampaian laporan keuangan oleh kuasa pengguna anggaran, maka diberlakukan sanksi administratif sebagai berikut (SAP, $2006: 45)$ :

a. Setiap keterlambatan penyampaian Laporan Keuangan oleh Pengguna Anggaran/kuasa Pengguna Anggaran pada tingkat pemerintah pusat yang disebabkan oleh kesengajaan dan kelalaian, Menteri Keuangan selaku Bendahara Umum Negara dapat memberi sanksi berupa penangguhan pelaksanaan anggaran atau penundaan pencairan dana. Setiap keterlambatan penyampaian Laporan Keuangan oleh Pengguna Anggaran/kuasa Pengguna Anggaran pada tingkat pemerintah daerah yang disebabkan oleh kesengajaan dan kelalaian, kepala satuan kerja pengelola keuangan daerah selaku Bendahara Umum Daerah dapat memberi sanksi berupa penangguhan pelaksanaan anggaran atau penundaan pencairan dana.

b. Ketentuan lebih lanjut mengenai tata cara pemberian sanksi sebagaimana dimaksud pada ayat (1) diatur dengan Peraturan Menteri Keuangan.

c. Ketentuan lebih lanjut mengenai tata cara pemberian sanksi sebagaimana dimaksud pada ayat (2) diatur dengan Peraturan Gubernur/Bupati/Walikota 
dengan mengacu pada pedoman yang ditetapkan dalam Peraturan Menteri Dalam Negeri.

d. Sanksi sebagaimana dimaksud pada ayat (1) dan ayat (2) tidak membebaskan kuasa Pengguna Anggaran dari kewajiban penyampaian Laporan Keuangan.

\section{Hasil Penelitian}

Dari hasil wawancara yang telah dilakukan dengan beberapa satker tersebut, maka dapat dikelompokkan faktor-faktor yang mempengaruhi keterlambatan penyampaian laporan keuangan pada satuan kerja sebagai berikut:

Faktor-Faktor Penyebab Keterlambatan Penyampaian Laporan Keuangan pada Satuan Kerja di Kantor Pelayanan Perbendaharaan Negara Solok Tahun 2017

\begin{tabular}{|c|c|c|c|c|c|c|}
\hline \multirow[b]{2}{*}{ No } & \multirow[b]{2}{*}{ Nama Satker } & \multicolumn{5}{|c|}{ Faktor- faktor keterlambatan } \\
\hline & & SDM & $\begin{array}{l}\text { Teknologi } \\
\text { Informasi }\end{array}$ & $\begin{array}{c}\text { Sarana } \\
\text { Pendukung }\end{array}$ & SPI & $\begin{array}{l}\text { Aturan } \\
\text { Hukum }\end{array}$ \\
\hline 1 & MAN Solok KotaSolok & 1 & 1 & $\mathbf{0}$ & $\mathbf{0}$ & $\mathbf{0}$ \\
\hline 2 & $\begin{array}{c}\text { MTsN Tembok Kacang } \\
\text { Kab Solok }\end{array}$ & 1 & 1 & 1 & 1 & 1 \\
\hline 3 & Polres Kota Solok & 1 & $\mathbf{0}$ & $\mathbf{0}$ & 1 & $\mathbf{0}$ \\
\hline 4 & $\begin{array}{l}\text { Dinas pertanian kab. } \\
\text { Solok }\end{array}$ & 1 & 1 & $\mathbf{0}$ & $\mathbf{0}$ & $\mathbf{0}$ \\
\hline 5 & MTSN Koto BaruSolok & 1 & 1 & $\mathbf{0}$ & 1 & $\mathbf{0}$ \\
\hline 6 & $\begin{array}{c}\text { Kementerian } \\
\text { AgamaKota Solok }\end{array}$ & 1 & $\mathbf{0}$ & $\mathbf{0}$ & $\mathbf{0}$ & 1 \\
\hline 7 & KPU Kab. Solok Selatan & 1 & 1 & $\mathbf{0}$ & $\mathbf{0}$ & $\mathbf{0}$ \\
\hline 8 & $\begin{array}{c}\text { Pengadilan Negeri } \\
\text { Solok }\end{array}$ & 1 & $\mathbf{0}$ & $\mathbf{0}$ & 1 & $\mathbf{0}$ \\
\hline 9 & $\begin{array}{c}\text { Pengadilan agama } \\
\text { solok }\end{array}$ & 1 & $\mathbf{0}$ & 1 & $\mathbf{0}$ & 1 \\
\hline 10 & KPU Kota Solok & 1 & 1 & $\mathbf{0}$ & $\mathbf{0}$ & $\mathbf{0}$ \\
\hline
\end{tabular}




\begin{tabular}{|c|c|c|c|c|c|}
\hline Jumlah & 10 & 6 & 2 & 4 & 3 \\
\hline Persentase & $40 \%$ & $24 \%$ & $8 \%$ & $16 \%$ & $12 \%$ \\
\hline
\end{tabular}

Sumber: Data diolah dari Hasil Wawancara

Dari sebanyak 10 satuan kerja di Kantor Pelayanan Perbendaharaan Negara Solok yang telah diwawancarai, 40\% keterlambatan penyampaian laporan keuangan disebabkan oleh fakor Sumber Daya Manusia (SDM), 24\% keterlambatan penyampaian laporan keuangan disebabkan oleh faktor teknologi informasi.

Sedangkan 8\% Keterlambatan penyampaian laporan keuangan disebabkan oleh faktor sarana pendukung. 16\% Keterlambatan penyampaian laporan keuangan disebabkan oleh faktor sistem pengendalian intern dan 12\% keterlambatan penyampaian laporan keuangan disebabkan oleh faktor aturan hukum.

Informasi akuntansi yang terdapat di dalam laporan keuangan pemerintah harus memenuhi beberapa karakteristik kualitatif, yaknirelevan, andal, dapat dibandingkan, dan dapat dipahami. Fakta yang terjadi dilapangan berdasarkan penelitian yang dilakukan ditemukan bahwa laporan keuangan yang disusun oleh satuan kerja Kantor Pelayanan Perbendaharaan Negara Solok, belum bisa memenuhi karakteristik kualitatif laporan keuangan.

Hal tersebut didasarkan dengan masih adanya laporan keuangan yang disampaikan oleh satuan kerja wilayah Kantor Pelayanan Perbendaharaan Negara (KPPN) Solok yang tidak tepat waktu. Laporan yang terlambat akan mengurangi atau menghilangkan relenvansinya. Hal ini akan berdampak pada pemanfaatan laporan keuangan dalam pengambilan keputusan. Selain itu, hal ini juga akan berdampak pada penyusunan Laporan Keuangan Pemerintah Pusat (LKPP).

Dari hasil wawancara yang telah dilakukan dengan satuan kerja wilayah Kantor Pelayanan Perbendaharaan Negara (KPPN) Solok berdasarkan indikator yang telah ditentukan sebagai faktor yang menyebabkan keterlambatan penyampaian laporan keuangan pada satker, diperoleh sebesar 40\% yang disebabkan oleh faktor sumber daya manusia, 24\% faktor teknologi informasi, 8\% faktor sarana pendukung, $16 \%$ faktor sistem pengendalian intern dan $12 \%$ faktor aturan hukum. 
Pada indikator sumber daya manusia, faktor yang dominan menyebabkan keterlambatan disebabkan karena kurang memahami pemahaman dibidang akuntansi yaitu sebesar 28,57 \%. Pada umumnya pegawai yang menyusun laporan keuangan pada satuan kerja kurang memahami pemahaman dibidang akuntansi ataupun keuangan.

Hal ini menyebabkan pegawai tersebut memiliki pemahaman yang minim mengenai akuntansi dan laporan keuangan. Kemampuan sumber daya manusia untuk menyusun laporan keuangan karena adanya pelatihan mengenai penyusunan laporan keuangan, baik dari pusat maupun dari Kementerian Keuangan.

Pada teknologi informasi, faktor yang dominan menyebabkan keterlambatannya dikarenakan update aplikasi yaitu $50 \%$. Aplikasi yang sering update menjadi kendala bagi satker dalam menyusun laporan keuangan. Belum lagi menguasai aplikasi sebelumnya, diterapkan pula dengan aplikasi yang baru. Hal ini menyebabkan pegawai yang menyusun laporan keuangan kesulitan dalam memahami aplikasi.

Permasalahan lain mengenai aplikasi ini yaitu terjadinya perbedaan waktu mengupdate aplikasi antara Kantor Pelayanan Perbendaharaan Negara Solok dan satuan kerja. Kantor Pelayanan Perbendaharaan Negara Solok telah mengupdate aplikasi, sementara satuan kerja belum. Hal ini menyebabkan data laporan keuangan antara satuan kerja dan Kantor Pelayanan Perbendaharaan negara Solok menjadi tidak sinkron.

Pada sarana pendukung faktor dominannya disebabkan internet yaitu sebesar 77.78\%. Jaringan internet maupun wifi merupakan sarana pendukung bagi satker dalam penyusunan laporan keuangan melalui berbagai aplikasi. Jaringan internet maupun wifi yang dimiliki satker kurang memadai serta seringkali bermasalah sehingga menjadi kendala bagi satker dalam menyusun laporan keuangan.

Dengan kendala tersebut, menyebabkan satker terlambat dalam menyampaikan laporan keuangannya. Pada sistem pengendalian intern yatu sebesar 80\% karena tidak adanya pemisahan tugas di unit organisasi. Tidak adanya pemisahan tugas di unit organisasi ini membuat pegawai memiliki rangkap jabatan dalam menjalankan tugasnya.

Disamping bertanggung jawab sebagai bendahara juga langung bertanggung jawab sebagai operatornya dan masih banyak lagi tanggung jawab lainnya setiap bendahara masing-masing satker. Pemisahan tanggung jawab dalam organisasi sangat penting dilakukan, karena hal itu merupakan unsur pokok dalam sistem pengendalian intern. 
Jika hal tersebut tidak dilakukan maka menyebabkan pegawai menjadi kewalahan dalam menjalankan tugas yang rangkap, sehingga tugas yang dikerjakan menjadi kurang maksimal contohnya satker terlambat dalam menyampaikan laporan keuanganya.

Aturan hukum sebagai faktor keterlambatan yang dialami oleh $12 \%$ satker, faktor ini disebabkan karena minimnya pemahaman satker mengenai Peraturan Pemerintah tentang Pengelolaan dan pertanggungjawaban penggunaan dana APBN. Peraturan pemerintah ini tidak bisa dipahami secara keseluruhan oleh pegawai yang menyusun laporan keuangan.

Selain faktor-faktor keterlambatan penyampaian laporan keuangan yang telah ditentukan sebagai indikator, ada faktor lain yang dapat menyebabkan keterlambatan penyusunan dan penyampaian laporan keuangan pada satuan kerja di Kantor Pelayanan Perbendaharaan Negara (KPPN) Solok. Faktor-faktor tersebut diantaranya akses wilayah, komunikasi elektronik yang belum memadai dan kurangnya operator/Custumer Servis (CS) di Kantor Pelayanan Perbendaharaan Negara (KPPN) Solok .

Pertama, akses wilayah menjadi penyebab keterlambatan penyampaian laporan keuangan pada satuan kerja. Seperti satker yang berada di wilayah luar kab. Solok memiliki jarak yang jauh dengan Kantor Pelayanan Perbendaharaan Negara Solok.

Selain itu, menyebabkan penerimaan surat yang dikirim oleh Kantor Pelayanan Perbendaharaan Negara (KPPN) Solok kepada satker melalui pos menjadi terlambat. Kedua, jumlah operator/Custumer Servis (CS) di Kantor Pelayanan Perbendaharaan Negara Solok yang kurang memadai untuk satuan kerja wilayah lingkup Kantor Pelayanan Perbendaharaan Negara (KPPN) Solok yang berjumlah 84 satker. Hal tersebut menyebabkan satker sering mengantri lama untuk melakukan rekonsiliasi, sehingga satker dapat terlambat menyampaikan laporan keuangannya.

Ketiga, sering terjadinya perubahan aplikasi dan kurangnya pengetahuan satuan kerja di kantor pelayanan perbendaharaan negara solok terhadap aplikasi baru yang diterapkan. Sehingga banyak terjadi kesalahan dalam meng-update data yang akhirnya menyebabkan keterlambatan dalam penyampaian laporan keuangan. Laporan yang dihasilkan oleh satuan kerja terkadang tidak sesuai dengan laporan yang telah dikirimkan kekantor pelayanan perbendaharaan negara solok. 


\section{Kesimpulan}

Penyebab terbesar keterlambatan dalam penyampaian laporan keuangan pada satker tersebut yaitu latar belakang pendidikan pegawai pada Sumber Daya Manusia, aplikasi dalam penyusunan laporan keuangan satker pada teknologi informasi, internet sebagai faktor pendukung dalam penyusunan laporan keuangan pada sarana pendukung, rangkap jabatan (tidak ada pemisahan tugas) sebaga faktor sistem pengendalian intern dan pemahaman Peraturan Pemerintah mengenai Pelaporan Keuangan.

\section{DAFTAR PUSTAKA}

Mardiasmo. 2009. Akuntansi Sektor publik. Yogyakarta : Andi .

Peraturan Menteri Keuangan No. 177 /PMK. 05 / 2015.Tentang pedoman penyusunan dan penyampaian laporan keuangan kementerian negara / lembaga.

Peraturan pemerintah republik indonesia nomor 8 tahun 2006. tentang pelaporan keuangan dan kinerja instansi pemerintah.

Sadeli, Lili. M. 2015. Dasar - dasar akuntansi . Jakarta : Bumi Aksara.

Sondang P. Siagian. 2009. Kiat meningkatkan produktivitas kerja. Jakarta : Rineka Cipta.

Sutabri.T. 2014. Pengantar teknologi informasi. Yogyakarta : Andi.

Yakup. 2012. Pengantar system informasi. Yogyakarta :GrahaIlmu. 